\title{
COMPOSIÇÃO QUÍMICA DA SOLUÇÃO DE SOLO SOB DIFERENTES COBERTURAS VEGETAIS E ANÁLISE DE CARBONO ORGÂNICO SOLÚVEL NO DEFLÚVIO DE PEQUENOS CURSOS DE ÁGUA ${ }^{(1)}$
}

\author{
Josias Miranda ${ }^{(2)}$, Liovando Marciano da $\operatorname{Costa}^{(3)}$, \\ Hugo Alberto Ruiz ${ }^{(3)} \&$ Rosilene Einloft ${ }^{(4)}$
}

\begin{abstract}
RESUMO
O cultivo intensivo pode alterar a composição química da solução do solo, favorecendo a perda de solutos. Dessa forma, poderia mudar a composição química dos cursos de água. Foi realizado um estudo na fazenda da EPAMIG em Oratórios, Minas Gerais, de junho de 1996 a maio de 1997, para avaliar o efeito do manejo do solo na composição química da solução do solo, considerando as condições climáticas. O carbono orgânico solúvel também foi determinado na solução do solo e no deflúvio de pequenos cursos de água. Foram realizadas extrações mensais da solução do solo sob diferentes coberturas vegetais, nas camadas de 0-20, 20-40 e 40-100 cm de profundidade. A extração da solução do solo foi feita por centrifugação, a uma força centrífuga relativa correspondente a $900 \mathrm{~g}$. Em acréscimo, foram feitas coletas semanais de deflúvio de quatro pequenos cursos de água com uso variado de suas respectivas áreas de drenagem. Foi observada uma ligeira elevação na concentração de íons em solução com o início do período chuvoso, sendo esse fato mais acentuado para o carbono orgânico solúvel na solução do solo e no deflúvio. A adubação mineral promoveu o deslocamento de íons trocáveis, em profundidade. A lixiviação foi favorecida, principalmente, no solo sem cobertura vegetal. A movimentação de carbono orgânico solúvel foi maior no solo sob pastagem, apesar do menor teor na solução do solo, em comparação aos outros solos. No curso de água drenado em área de pastagem, também foi encontrada a maior concentração de carbono orgânico solúvel.
\end{abstract}

Termos de indexação: lixiviado, pH, condutividade elétrica, nutrientes catiônicos, alumínio.

\footnotetext{
(1) Parte da Tese de Doutorado, apresentada pelo primeiro autor à Universidade Federal de Viçosa - UFV. Recebido para publicação em maio de 2005 e aprovada em maio de 2006.

(2) Engenheiro-Agrônomo do Ministério da Agricultura. Explanada dos Ministérios, Bloco D, CEP 70043-900 Brasília (DF). E-mail: josiasm@agricultura.gov.br

(3) Professor do Departamento de Solos, Universidade Federal de Viçosa - UFV. CEP 36570-000 Viçosa (MG). Bolsista do CNPq. E-mail: liovandomc@yahoo.com.br; hruiz@ufv.br

${ }^{(4)}$ Engenheira Florestal. CEP 36570-000 Viçosa (MG). E-mail: reinloft@uol.com.br
} 


\title{
SUMMARY: CHEMICAL COMPOSITION OF SOIL SOLUTION UNDER DIFFERENT LAND COVER AND SOLUBLE ORGANIC CARBON IN WATER FROM SMALL CREEKS
}

\begin{abstract}
Intensive land use can change the chemical composition of the soil solution and cause solute losses. Thus, it can alter the chemical composition of water courses. A study was carried out in a farm of EPAMIG in Oratorios, state of Minas Gerais, Brazil, from June 1996 to May 1997, to evaluate the effect of soil management on the chemical composition of soil solution, taking climatic conditions into consideration. Soluble organic carbon was also determined in the soil solution and in water streams of small watersheds. Soil solution was extracted monthly from soils under different land uses from three layers: 0 to 20, 20 to 40 and 40 to $100 \mathrm{~cm}$. The soil solution was extracted by centrifugation, at a relative centrifuge force of $900 \mathrm{~g}$. Additionally, water samples were collected from four creeks draining out of watersheds under different land uses. A slight increase in the ion concentration was observed in the soil solution in the beginning of the wet season. The changes were pronounced for the soluble organic carbon in the soil solution and water streams. Soil fertilization promoted the displacement of exchangeable ions to the soil solution down through the soil profile. The highest soil leaching was found for the bare soil. The soluble organic carbon movement across the soil profile was higher under pasture, even though its concentration was the lowest compared to the other land uses. The highest soil organic carbon was observed in water of a creek draining out of a pasture watershed.
\end{abstract}

Index terms: leachate, $p H$, electrical conductivity, cationic nutrients, aluminum.

\section{INTRODUÇÃO}

O solo é uma massa porosa, com parte dos espaços vazios normalmente ocupados pela água. $\mathrm{Na}$ realidade, não se trata de água pura, mas de uma solução que contém diversos solutos que influem no desenvolvimento das plantas.

Mesmo em um ecossistema em estado natural, ocorrem modificações de umidade e temperatura em decorrência de variações climáticas que influenciam os processos físico-químicos e biológicos do solo, modificando algumas características, tais como: umidade do solo, atividade microbiológica, teor e composição da matéria orgânica, complexo argilohúmico, capacidade de troca catiônica e lixiviação de nutrientes.

A disponibilidade dos íons para as raízes das plantas é controlada por várias reações, a saber: equilíbrio entre ácido e base, complexação iônica, precipitação e dissolução de sólidos, oxidação, redução e trocas iônicas. A cinética dessas reações e a taxa de absorção biológica controlam a concentração do íon na solução de solo (Chaves et al., 1991).

A absorção de elementos químicos pelas raízes das plantas dá-se a partir da solução do solo (Raij, 1991). O conhecimento da composição química da solução de solo fornece subsídios importantes para o entendimento das alterações físicas e químicas advindas do uso e manejo e para o monitoramento das várias práticas de melhoramento do solo (Simard et al., 1988; Campbell et al., 1989). Pode também auxiliar nas estimativas da taxa de intemperismo, na taxa de ciclagem dos elementos químicos e no influxo e lixiviação de nutrientes no campo.

Com o advento da industrialização e a expansão agropecuária, aliados a um elevado grau de consumismo, houve quebra do equilíbrio natural de grande parte dos ecossistemas. A deterioração da qualidade da água é uma das primeiras conseqüências advindas do uso e manejo inadequados dos recursos naturais (Quian et al., 1994).

As atividades antrópicas têm prejudicado a qualidade e quantidade da água, especialmente a água superficial, pela descarga de efluentes sem qualquer tratamento. O uso e o manejo inadequados de fertilizantes e agrotóxicos têm deteriorado a qualidade das águas superficiais.

Nesse contexto, o objetivo deste trabalho foi avaliar a influência do uso e manejo do solo e variações temporais, decorrentes das condições climáticas, na concentração dos elementos químicos na solução do solo e do carbono orgânico solúvel na solução e no deflúvio de pequenos cursos de água.

\section{MATERIAL E MÉTODOS}

O estudo foi realizado em área experimental da Empresa de Pesquisa Agropecuária de Minas Gerais (EPAMIG), situada no km 12 da rodovia Ponte NovaOratórios, MG.

A precipitação pluviométrica registrada foi de $1.482 \mathrm{~mm}$, no período de 15 de agosto de 1996 a 31 
julho de 1997 (dados quinzenais), no Posto Meteorológico da Central de Pesquisa e Experimentação da Canade-Açúcar (CECA) da Universidade Federal de Viçosa, a, aproximadamente, $1 \mathrm{~km}$ da área experimental.

Parcelas de 6 × $6 \mathrm{~m}$ foram delimitadas em dois solos sob dois sistemas de manejo: (a) Latossolo VermelhoAmarelo sem cobertura vegetal (LVA(Ad)) e sob cafezal (LVA(Cf)); (b) Argissolo Câmbico sob pastagem $(\mathrm{PVA}(\mathrm{Pa}))$ e sob mata nativa (PVA(Mt)), conforme caracterização (química e física) apresentada no quadro 1. As coletas mensais de amostras de solo para extração da solução foram efetuadas nas camadas de 0-20, 20-40 e 40-100 cm de profundidade, com três repetições, no período de junho de 1996 (mês 6) a maio de 1997 (mês 5).

O método utilizado na extração da solução de solo foi o da centrifugação, descrito por Gillman (1976), com algumas adaptações (Miranda, 1993). A umidade do solo foi elevada até $-10 \mathrm{kPa}$, sendo as amostras incubadas por quatro dias e submetidas a uma força centrífuga relativa correspondente a $900 \mathrm{~g}$, por 40 minutos, para extração da solução de solo.

Na solução de solo, foram determinados: $\mathrm{pH}$, por potenciometria; condutividade elétrica (CE), por condutivimetria; $\mathrm{Ca}^{2+}, \mathrm{Mg}^{2+} \mathrm{e} \mathrm{Fe}$, por espectrofotometria de absorção atômica; $\mathrm{Na}^{+}$e $\mathrm{K}^{+}$, por fotometria de emissão de chama; $\mathrm{Al}^{3+}$, por colorimetria, pelo método do aluminon (McLean, 1965); $\mathrm{SO}_{4}{ }^{2-}$, por turbidimetria

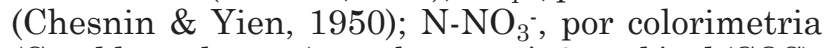
(Cataldo et al., 1974) e carbono orgânico solúvel (COS), determinado colorimetricamente pelo método descrito por Bartlett \& Ross (1988).

Amostras do deflúvio foram coletadas semanalmente, no período de $1^{\circ}$ de agosto de 1996 (semana 1) a 31 de julho de 1997 (semana 52), no curso da água número 1, denominado "misto", com predominância de cultivos anuais e pastagem na área de drenagem. Na área drenada pelo córrego 2, denominado "pasto", predominava pastagem de capim-meloso (Mellinis minutiflora Pal. De Beauv.). No número 3, "mata nativa", com predominância de mata natural. O último ponto de coleta (4) localizava-se em represa na saída da área experimental, sendo, portanto, denominado "represa", com uso de sua área de drenagem também bastante diversificado, como no córrego misto.

Na solução do deflúvio, foram determinados: o pH, por potenciometria; a condutividade elétrica, por condutivimetria, e o carbono orgânico solúvel (COS), determinado colorimetricamente pelo método descrito por Bartlett \& Ross (1988).

\section{RESULTADOS E DISCUSSÃO}

\section{Caracterização química da solução de solo pH da solução de solo}

A variação temporal do $\mathrm{pH}$ da solução de solo e o seu comportamento nas três camadas em estudo são apresentados na figura 1 , na qual se verifica ligeira redução do $\mathrm{pH}$ em todos os solos, nos primeiros meses. Essa redução foi mais acentuada no Latossolo Vermelho-Amarelo sem cobertura vegetal, onde a lixiviação de bases mostrou-se mais intensa. A diminuição do $\mathrm{pH}$ da solução pode ser atribuída à elevação da concentração de $\mathrm{H}^{+}$no meio pelo aumento da decomposição da matéria orgânica, advinda da atividade microbiana com o início do período chuvoso após um período de seca (Alexander, 1977).

Constatou-se que a solução do solo sob cafeeiro foi mais ácida que as demais soluções de solos sob outras coberturas vegetais, sendo esse efeito mais acentuado em profundidade (Figura 1). O Latossolo Vermelho-

Quadro 1. Caracterização física e química de materiais de Latossolo Vermelho-Amarelo sem cobertura vegetal (LVA(Ad)) e sob cafeeiro (LVA(Cf)) e de Argissolo Câmbico sob mata (PVA(Mt)) e sob pastagem (PVA(Pa)) na camada de 0-20 cm de profundidade

\begin{tabular}{|c|c|c|c|c|}
\hline Característica & LVA(Ad) & LVA(Cf) & PVA(Mt) & PVA(Pa) \\
\hline Areia $\mathrm{g} \mathrm{kg} \cdot 1$ & 394 & 403 & 613 & 387 \\
\hline Silte $\mathrm{g} \mathrm{kg}^{-1}$ & 108 & 111 & 130 & 207 \\
\hline Argila g kg-1 & 498 & 486 & 257 & 406 \\
\hline Equivalente de umidade $\mathrm{m}^{3} \mathrm{~m}^{-3}$ & 0,258 & 0,260 & 0,218 & 0,296 \\
\hline $\mathrm{Ca}^{2+} \mathrm{mmol}_{\text {c dm}}{ }^{-3}$ & 11,05 & 9,58 & 4,88 & 7,88 \\
\hline $\mathrm{Mg}^{2+} \mathrm{mmol}_{\mathrm{c}} \mathrm{dm}^{-3}$ & 4,25 & 4,52 & 2,74 & 2,63 \\
\hline $\mathrm{Al}^{3+} \mathrm{mmol}_{\mathrm{c} \mathrm{dm}^{-3}}$ & 7,83 & 15,93 & 6,63 & 3,27 \\
\hline $\mathrm{K} \mathrm{mg} \mathrm{dm}-3$ & 120,82 & 151,51 & 65,36 & 110,38 \\
\hline $\mathrm{Na} \mathrm{mg} \mathrm{dm}^{-3}$ & 2,04 & 2,72 & 2,81 & 3,86 \\
\hline Matéria orgânica g kg-1 & 47,00 & 38,07 & 30,67 & 45,33 \\
\hline
\end{tabular}


Amarelo sob cafeeiro foi adubado, duas vezes ao ano, com cerca de 250 g por cova da fórmula 20-5-20 para cada aplicação. Além disso, também foi adicionado gesso a esse solo. Outro fator, que pode ter contribuído para redução do $\mathrm{pH}$, principalmente no Latossolo Vermelho-Amarelo sob cafeeiro, é o ânion $\mathrm{NO}_{3}$. Este, em geral, provém da nitrificação do íon amônio, seja ele originado da matéria orgânica do solo, seja de adubos nitrogenados, seja até mesmo de adubos verdes ou orgânicos.

A elevação da força iônica da solução constatada pelo aumento da condutividade elétrica (Figura 1) pode também ter contribuído para a redução do $\mathrm{pH}$ na solução do solo sob cafeeiro. Vários trabalhos têm demonstrado que a força iônica da solução altera a acidez do solo.

A perda de $\mathrm{CO}_{2}$ do solo durante a amostragem, o transporte e a centrifugação para extração da solução de solo podem ter influenciado o $\mathrm{pH}$ da solução. $\mathrm{O} \mathrm{pH}$ médio mensal da solução de solo variou de 4,3 a 5,3, sendo mais elevado que o $\mathrm{pH}$ do solo (Quadro 1). Em média, o $\mathrm{pH}$ da solução foi superior ao do solo em 34,8 \% no solo sob mata; $22,6 \%$, no solo sob pastagem; $32,6 \%$, no solo sem cobertura vegetal, e $26,8 \%$, no solo sob cafeeiro. Resultados com tendências semelhantes foram encontrados por Adams et al. (1980), Miranda (1993) e Su \& Evans (1996), enquanto
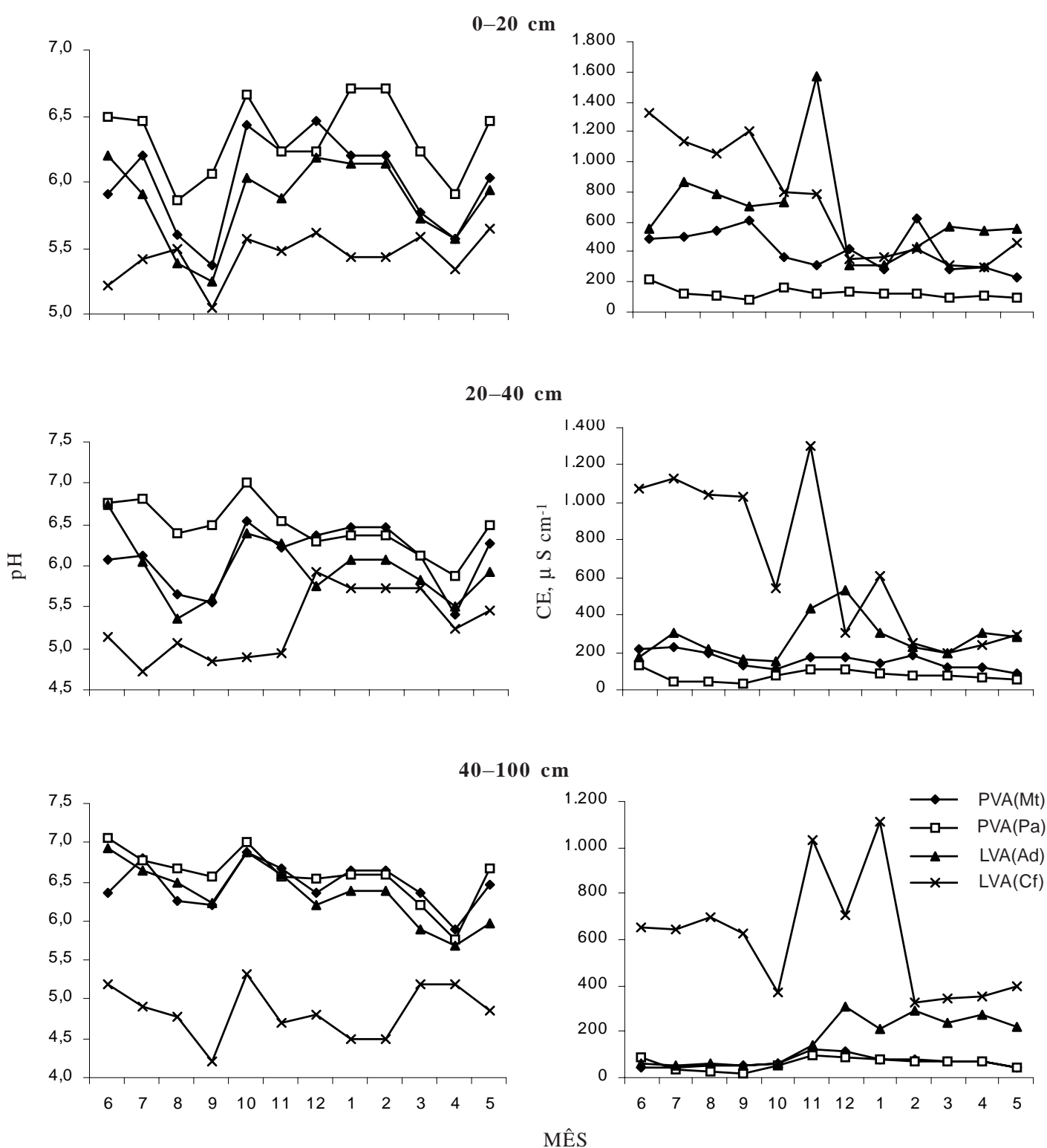

Figura 1. Variação mensal do pH e da condutividade elétrica (CE) na solução do Argissolo Câmbico sob mata (PVA(Mt)) e sob pastagem (PVA(Pa)) e do Latossolo Vermelho-Amarelo sem cobertura vegetal (LVA(Ad)) e sob cafeeiro (LVA(Cf)), no período de junho de 1996 a maio de 1997, em três profundidades. Média de três repetições. 
Wolt \& Gravel (1986), Elkhatib et al. (1987), Curtin \& Simillie (1995), Ross \& Bartlett (1996) e Andreola (1996) encontraram valores de $\mathrm{pH}$ da solução próximos ou inferiores aos do $\mathrm{pH}$ do solo.

Outro fator que, possivelmente, pode distanciar ou aproximar o $\mathrm{pH}$ da solução de solo do $\mathrm{pH}$ do solo seria a proporção solo: água. $\mathrm{Na}$ determinação do $\mathrm{pH}$ em água, a relação solo:água utilizada foi de $1: 2,5$. Na extração da solução de solo, a relação foi cerca de 1:0,3. Sabe-se que o pH da solução varia de acordo com a concentração eletrolítica da solução de solo. Nesse contexto, esperava-se que o $\mathrm{pH}$ da solução de solo extraída por centrifugação fosse menor que o do solo, visto que, pelo efeito de diluição, o $\mathrm{pH}$ do solo em água tende a se aproximar do $\mathrm{pH}$ da água. Entretanto, outros fatores, tais como; composição iônica da solução, decomposição da matéria orgânica, retirada de $\mathrm{CO}_{2}$ e força iônica da solução influenciaram o pH da solução de solo.

\section{Condutividade elétrica da solução de solo}

A condutividade elétrica é um indicador da concentração de íons na solução de solo e, no presente estudo, variou de acordo com o uso do solo (Figura 1). $\mathrm{O}$ solo sob pastagem apresentou o menor valor de condutividade elétrica, enquanto o solo sob cafeeiro com adição de fertilizantes químicos exibiu os maiores valores. Na camada superficial, verificou-se que o solo sob mata natural apresentou valores de $\mathrm{CE}$ superiores aos do solo sob pastagem, indicando ser este um ecossistema mais conservador de nutrientes.

Os solos sob mata natural e pastagem apresentaram padrão de variação da condutividade elétrica ao longo do período em estudo diferente do apresentado pelo solo sem cobertura vegetal e sob cafeeiro, ambos adubados (Figura 1). Os coeficientes de variação médios mensais em todas as profundidades ao longo do ano foram de $35 \%$, nos solos sem adubação mineral (PVA(Mt) e PVA(Pa)), e de $53 \%$, em solos com adubação (LVA(Ad) e LVA(Cf)).

No solo sob cafeeiro, foi possível verificar o efeito da lixiviação de nutrientes após a adubação mineral. Os valores de condutividade elétrica aumentaram em profundidade, evidenciando a movimentação de elementos químicos. A ausência de picos acentuados de elevação de CE em profundidade no solo sem cobertura vegetal com adubação mineral pode ser devida à periodicidade da amostragem. A extração mensal da solução de solo não foi suficiente para detectar a lixiviação de nutrientes em área descoberta, que deve ter sido intensa, considerando-se, ainda, que a precipitação pluviométrica no período foi elevada.

Pela figura 1, constata-se que, nos solos adubados, os níveis de estabilização da condutividade elétrica após o período de chuvas (a partir do nono mês) foram bastante próximos nas três profundidades estudadas. Esse fato demonstra que as perdas por lixiviação de nutrientes podem ser muito altas e, mesmo nos solos adubados, podem ocorrer deficiências em algumas épocas.

\section{Cálcio na solução de solo}

As concentrações médias de cálcio na solução de solo no sexto mês, na camada superficial (Figura 2), foram de, aproximadamente, 1,$1 ; 0,2 ; 1,9$; e 2,5 $\mathrm{mmol} \mathrm{L}^{-1}$, respectivamente, para PVA(Mt), PVA(Pa), LVA(Ad) e $\mathrm{LVA}(\mathrm{Cf})$. Tais valores diminuíram acentuadamente a partir do $12^{\circ}$ mês.

Os resultados indicaram que a adubação com NPK (20-5-20) no Latossolo Vermelho-Amarelo sem cobertura vegetal elevou, abruptamente, os teores de cálcio em solução, principalmente na camada superficial. No Latossolo Vermelho-Amarelo sob cafeeiro, o aumento de $\mathrm{Ca}^{2+}$ foi verificado somente nas camadas subsuperficiais. Verificou-se, também, elevação acentuada da concentração de $\mathrm{Ca}^{2+} \mathrm{em}$ solução no sexto mês; quase que simultaneamente à diminuição de cálcio na camada superficial, detectouse pequeno aumento na camada intermediária e, posteriormente, na camada de 40-100 cm (Figura 2). Esse fato indicou que o $\mathrm{Ca}^{2+}$ foi deslocado dos sítios de troca e movimentou-se ao longo do perfil.

Os valores médios trimestrais dos teores de $\mathrm{Ca}^{2+}$ na camada superficial do solo decresceram na seguinte ordem: LVA $(\mathrm{Ad})>\mathrm{LVA}(\mathrm{Cf})>\mathrm{PVA}(\mathrm{Pa})>\mathrm{PVA}(\mathrm{Mt})$. $\mathrm{Na}$ solução de solo, os teores de $\mathrm{Ca}^{2+}$ não seguiram a mesma seqüência, ou seja: LVA (Cf) > LVA (Ad) > $\mathrm{PVA}(\mathrm{Mt})>\mathrm{PVA}(\mathrm{Pa})$. No solo sob mata natural, as variações porventura existentes na solução de solo foram, provavelmente, decorrentes de variações climáticas, lixiviação de copa e tronco da floresta, atividade microbiana e sazonalidade na absorção de nutrientes pela vegetação.

\section{Magnésio na solução de solo}

As curvas de magnésio na solução de solo em todos os tratamentos apresentaram comportamento, ao longo do período estudado, semelhante ao das curvas de cálcio (Figura 2). No início do período chuvoso, houve elevação do teor de magnésio na solução de solo, principalmente na camada superficial.

Verificou-se que a aplicação do fertilizante NPK (20-5-20), a partir de outubro de 1996, aumentou os teores de magnésio na solução, na camada superficial, em Latossolo Vermelho-Amarelo sem cobertura vegetal (LVA(Ad)). A ausência de picos acentuados na concentração de $\mathrm{Mg}^{2+}$, nas camadas mais profundas, indicou que a lixiviação foi intensa nesse solo, tendo sido a extração mensal de solução de solo insuficiente para detectá-la.

Ao contrário do solo sem cobertura vegetal, o retardamento da movimentação de $\mathrm{Mg}^{2+}$ no solo sob cafeeiro deveu-se, provavelmente, à absorção pelas plantas e aos restos de material orgânico em vários estádios de decomposição existentes na projeção da copa do cafeeiro, os quais, possivelmente, retardaram a solubilização do fertilizante. No entanto, a partir do sétimo, oitavo e nono mês, respectivamente, nas 
$0-20 \mathrm{~cm}$
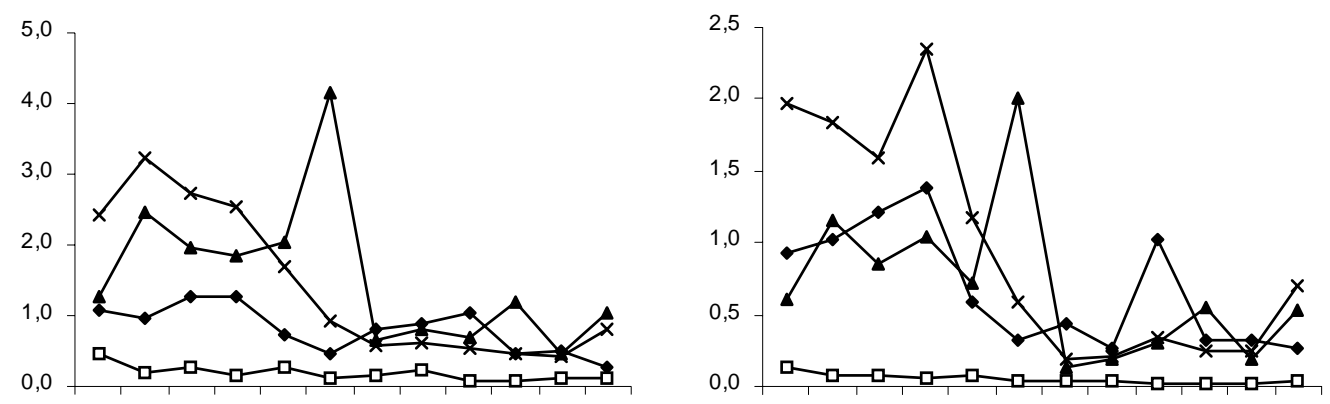

$20-40 \mathrm{~cm}$
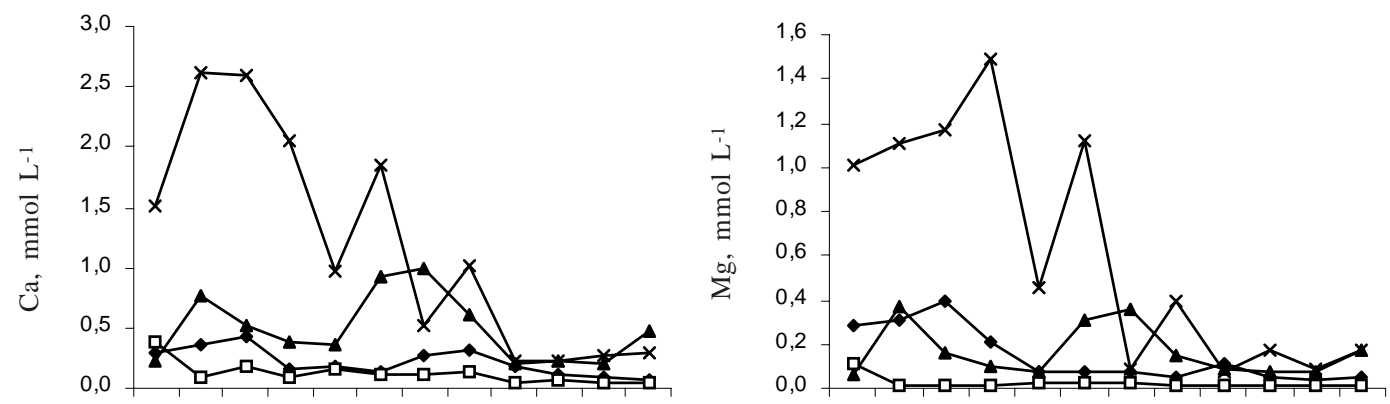

$40-100 \mathrm{~cm}$
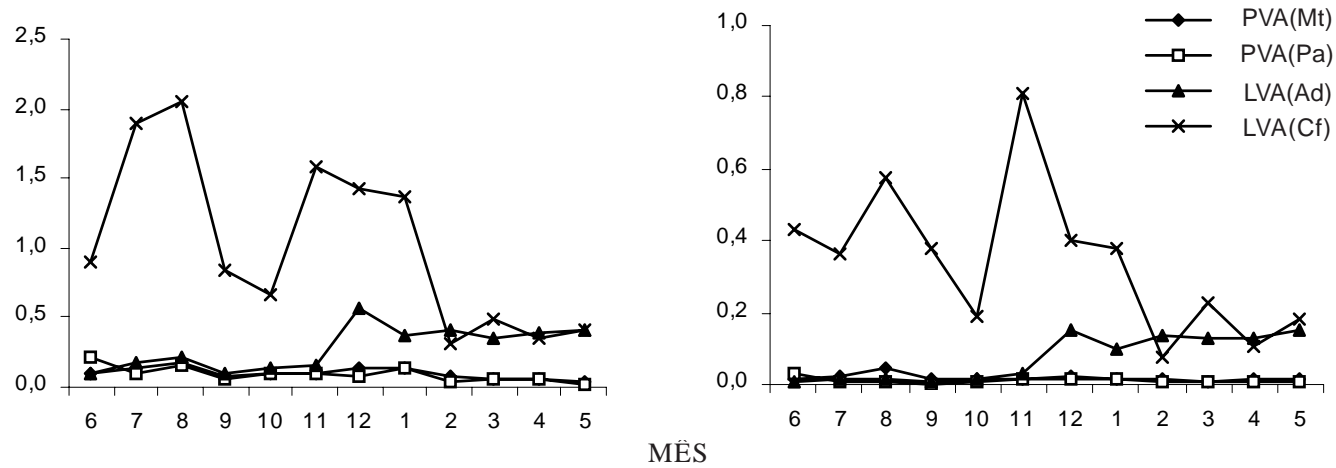

Figura 2. Variação mensal da concentração de cálcio e de magnésio na solução do Argissolo Câmbico sob mata (PVA(Mt)) e sob pastagem (PVA(Pa)) e do Latossolo Vermelho-Amarelo sem cobertura vegetal (LVA(Ad)) e sob cafeeiro (LVA(Cf)), no período de junho de 1996 a maio de 1997, em três profundidades. Média de três repetições.

camadas de 0-20, 20-40 e 40-100 cm, houve estabilização na concentração de $\mathrm{Mg}^{2+}$ em patamares, semelhantes tanto no LVA(Ad) quanto no LVA(Cf).

\section{Potássio na solução de solo}

O potássio na solução de solo (Figura 3) apresentou comportamento semelhante ao do solo, ou seja, a adubação com a fórmula 20-5-20 aumentou os teores de potássio na solução de solo, principalmente no solo sob cafeeiro, a partir de outubro de 1996.

Em geral, as curvas de potássio em solução seguiram as mesmas tendências observadas para o cálcio e para o magnésio, embora se percebesse certo desbalanço, já que seus teores eram maiores do que os de $\mathrm{Mg}^{2+}$ e bem próximos aos de $\mathrm{Ca}^{2+}$ em solução.

A lixiviação do potássio no solo sem cobertura vegetal foi intensa, e, tal como ocorreu com o cálcio e com o magnésio, a amostragem mensal foi também insuficiente para detectar a variação na concentração de potássio advinda do processo de lixiviação, principalmente nas camadas de 20-40 e 40-100 cm de profundidade.

O maior teor de potássio na solução de solo sob cafeeiro, comparativamente ao solo sem cobertura vegetal, pode ser atribuído, em parte, à maior capacidade de troca catiônica do LVA $(\mathrm{Cf})$ e, portanto, à maior retenção do elemento, apesar do menor $\mathrm{pH}$ do 
solo e da solução em relação ao LVA (Ad). Um fato talvez de maior relevância é que parte do potássio pode encontrar-se imobilizada na cobertura de restos vegetais que recobrem o solo sob cafeeiro. Com a decomposição da matéria orgânica, esse potássio vai sendo liberado lentamente e mantendo, portanto, teores mais elevados em solução. Com o início do período seco, o teor do elemento diminui em solução, principalmente nas camadas mais profundas do solo.

\section{Sódio na solução de solo}

Os teores de sódio na solução de solo, ao contrário do que ocorreu com o potássio, não aumentaram na camada superficial (0-20 cm) com a adubação mineral do solo com NPK (20-5-20) (Figura 3).
Aumentos na concentração de sódio em solução foram verificados em todas as coberturas vegetais e em todas as camadas estudadas a partir do nono mês, com a intensificação das chuvas. Tal fato indicou uma inter-relação com a decomposição da matéria orgânica, já que entradas de sódio via precipitação pluvial, se existentes, são pequenas em virtude da ausência de poluição atmosférica. A elevação de sódio em profundidade (Figura 3) indica também ocorrência de translocação do elemento.

\section{Alumínio na solução de solo}

A concentração média mensal de alumínio na solução de solo diminuiu em profundidade no solo sob pastagem e sem cobertura vegetal. Nas camadas mais

0-20 cm
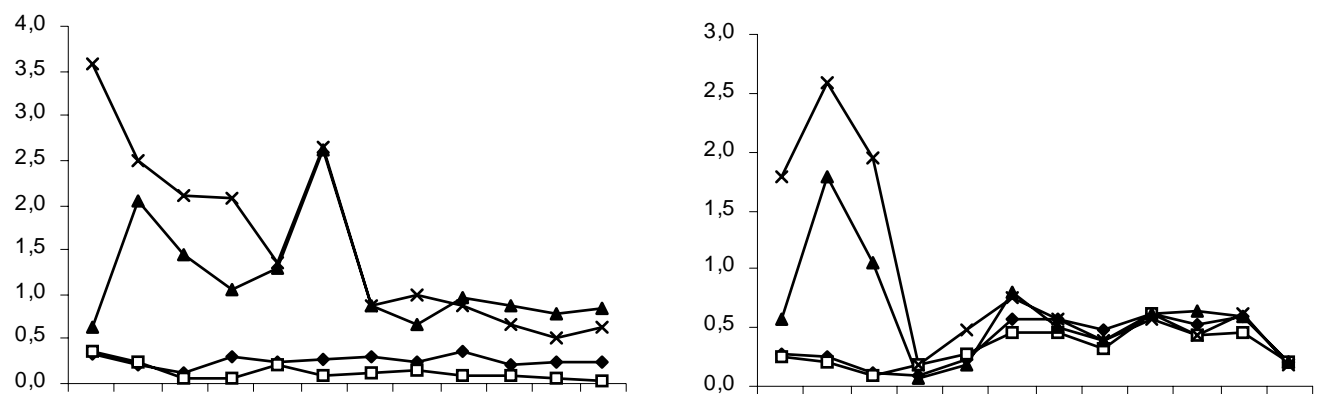

20-40 cm
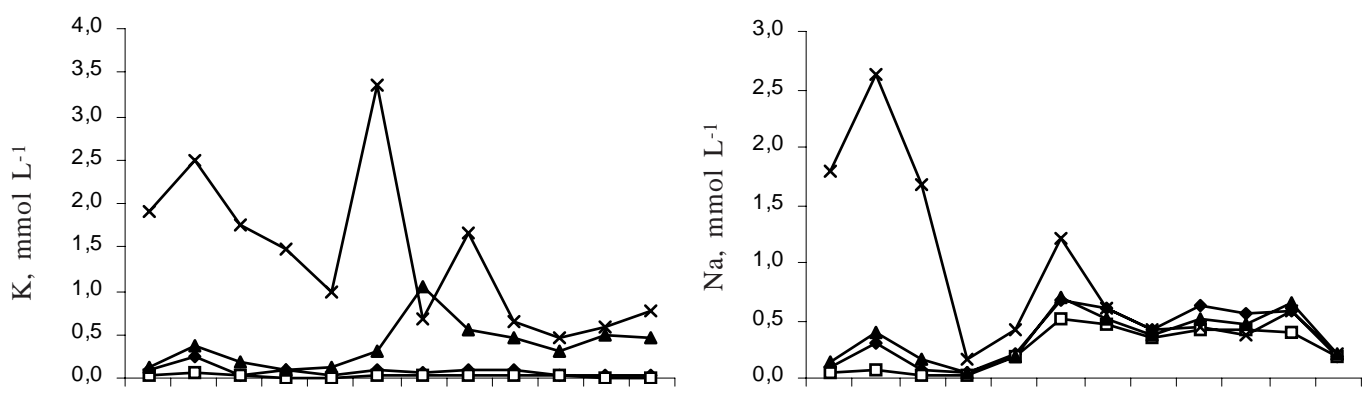

$40-100 \mathrm{~cm}$
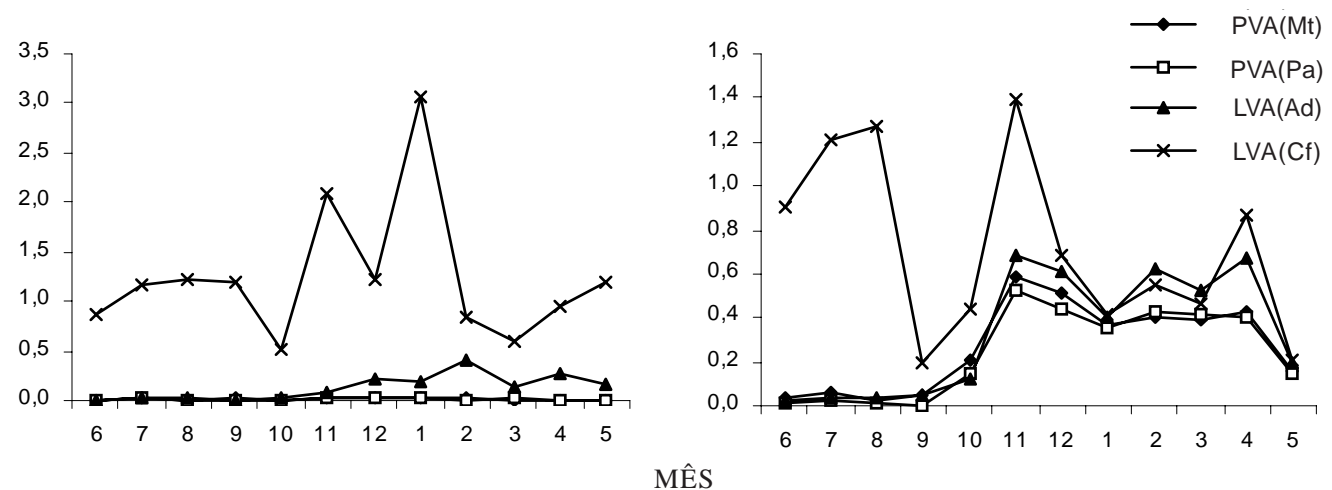

Figura 3. Variação mensal da concentração de potássio e de sódio na solução do Argissolo Câmbico sob mata (PVA(Mt)) e sob pastagem PVA(Pa) e do Latossolo Vermelho-Amarelo sem cobertura vegetal (LVA(Ad)) e sob cafeeiro (LVA(Cf)), no período de junho de 1996 a maio de 1997, em três profundidades. Média de três repetições. 
profundas, os teores de alumínio em solução de solo sob cafeeiro aumentaram de forma acentuada. O coeficiente de variação para o $\mathrm{Al}$ em solução (em média, $71 \%$ ) foi o mais elevado dentre os elementos analisados, só sendo ultrapassado pelo $\mathrm{N}-\mathrm{NO}_{3}$.

Verifica-se, na figura 4, que, com o aumento da umidade do solo, ocorreu ligeira elevação dos teores de $\mathrm{Al}$ em solução na camada superficial $(0-20 \mathrm{~cm})$, independentemente da cobertura vegetal, indicando associação entre essas variáveis. De acordo com Mendonça et al. (1991), nos solos de regiões tropicais, o complexo matéria orgânica-Al é muito importante no controle da toxidez por Al. A mineralização da matéria orgânica pode acarretar grande liberação de $\mathrm{Al}^{3+}$ para a solução de solo. Dessa forma, pecebe-se uma tendência a ocorrer maiores concentrações de $\mathrm{Al}^{3+}$ na solução de solo, principalmente na camada superficial, com a redução nos teores de COS (Figura 4).
A concentração de alumínio na solução de solo sob cafeeiro aumentou em profundidade (Figura 4), indicando uma movimentação de $\mathrm{Al}^{3+}$ provavelmente em decorrência da aplicação do gesso. Esse cafeeiro tinha aproximadamente sete anos de plantio, e foi realizada a aplicação de sulfato de cálcio antes de seu estabelecimento. Diversos estudos (Pavan, 1983; Chaves et al., 1991; Menzies et al., 1994) têm evidenciado aumento consistente na concentração de $\mathrm{Al}^{3+} \mathrm{em}$ solução, bem como elevação da força iônica e resultados conflitantes em relação ao aumento ou à diminuição do $\mathrm{pH}$ após a aplicação de sulfato de cálcio ao solo.

De acordo com Pavan (1983), o aumento da concentração de $\mathrm{Al}$ na solução de solo é decorrente da substituição do alumínio na fase trocável pelos íons de $\mathrm{Ca}^{2+}$. Segundo Chaves et al. (1991), embora os sais de cálcio com $\mathrm{Cl}^{-}$e $\mathrm{SO}_{4}{ }^{2-}$ tenham proporcionado aumentos na concentração de alumínio total em relação
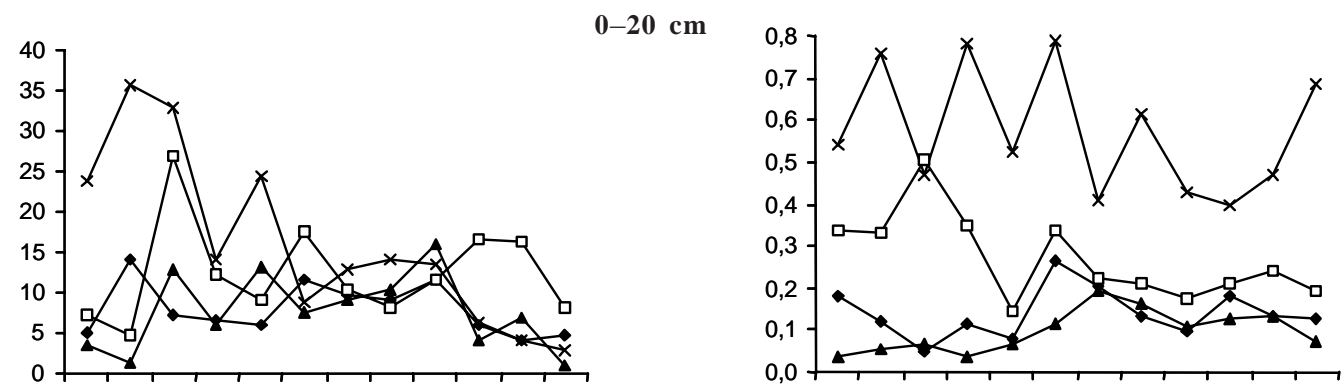

$20-40 \mathrm{~cm}$
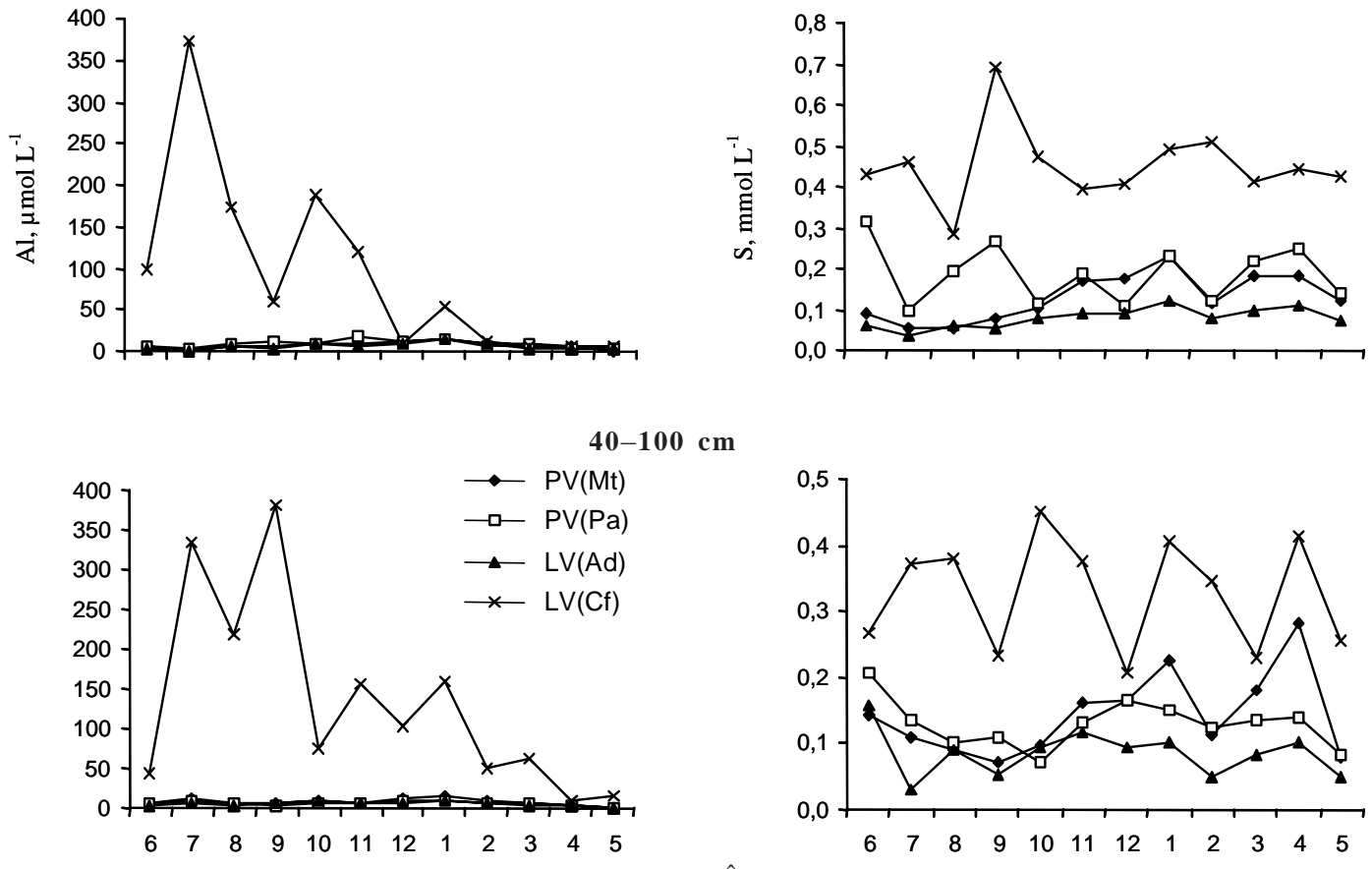

Figura 4. Variação mensal da concentração de alumínio e de enxofre na solução do Argissolo Câmbico sob mata (PVA(Mt)) e sob pastagem (PVA(Pa)) e do Latossolo Vermelho-Amarelo sem cobertura vegetal (LVA(Ad)) e sob cafeeiro (LVA(Cf)), no período de junho de 1996 a maio de 1997, em três profundidades. Média de três repetições. 
à testemunha, a especiação química dos íons utilizando o programa de computador Geohem indica que o $\mathrm{Al}^{3+}$ foi inferior no tratamento com sulfato de cálcio. Esse resultado deveu-se à formação do par iônico $\mathrm{AlSO}_{4}{ }^{+}$, diminuindo a concentração da forma livre $\left(\mathrm{Al}^{3+}\right)$.

\section{Enxofre na solução de solo}

$\mathrm{Na}$ camada de $0-20 \mathrm{~cm}$ de profundidade, a concentração média mensal de enxofre na solução variou de $0,098 \mathrm{mmol} \mathrm{L}^{-1}$, no solo sem cobertura vegetal a $0,572 \mathrm{mmol} \mathrm{L}^{-1}$, no solo sob cafeeiro. Após pequena diminuição nos primeiros meses, a concentração de enxofre aumentou ligeiramente a partir do $10^{\circ}$ mês na camada superficial (Figura 4). Como não foi adicionado enxofre no solo (exceto em solo sob cafeeiro), admite-se que o pequeno incremento de $\mathrm{SO}_{4}{ }^{2-}$ na solução de solo seja decorrente da decomposição da matéria orgânica do solo.

David \& Lawrence (1996) encontraram, em soluções de solo sob floresta, concentrações de enxofre variando de 27 a $93 \mu \mathrm{mol} \mathrm{L}^{-1}$, no horizonte $\mathrm{O}_{\mathrm{a}}$, e de 18,3 a $30,7 \mu \mathrm{mol} \mathrm{L}-1$, no horizonte B. No presente estudo, a concentração média mensal de enxofre na solução de solo sob mata foi de, aproximadamente, $140 \mu \mathrm{mol} \mathrm{L}^{-1}$, independentemente da camada. Os maiores valores encontrados na solução de solo sob mata neste trabalho podem ser atribuídos à maior decomposição da matéria orgânica.

A adubação do solo com NPK aumentou o teor de enxofre na solução (Figura 4). No solo sob cafeeiro, a concentração de enxofre em solução foi sempre superior à das demais coberturas vegetais em qualquer profundidade.

O solo sob cafeeiro, à época da instalação deste (sete anos atrás), recebeu adição de gesso, contribuindo, portanto, para aumentar o teor de enxofre em solução. Menzies et al. (1994) verificaram que o teor de enxofre em solução de solo aumentou de 0,24 para $14,1 \mu \mathrm{mol} \mathrm{L}{ }^{-1}$ após a adição de $\mathrm{CaSO}_{4} \cdot 2 \mathrm{H}_{2} \mathrm{O}$.

No solo sob cafeeiro, verificou-se a inexistência de indícios evidentes de translocação de enxofre, provavelmente graças à grande adsorção, já que o $\mathrm{pH}$ do solo e o da solução são bastante ácidos, apesar de ser a força iônica relativamente elevada e atuar no sentido de diminuir a adsorção. Segundo Marsh et al. (1987), quando o $\mathrm{pH}$ diminui, a adsorção de $\mathrm{SO}_{4}{ }^{2-}$ aumenta em virtude da protonação das superfícies minerais, criando-se mais sítios positivos de adsorção.

\section{Nitrogênio na solução de solo}

O adubo NPK (20-5-20) adicionado aos solos sem cobertura vegetal (LVA(Ad)) e sob cafeeiro (LVA(Cf)) aumentou o teor de $\mathrm{N}$ na solução de solo (Figura 5). O efeito foi mais pronunciado no LVA(Ad), na camada de 0-20 cm de profundidade, do $10^{\circ}$ para o $11^{\circ}$ mês. Posteriormente, com a diminuição do teor de $\mathrm{N}$ na camada superficial, verificaram-se pequenos acréscimos nas camadas de 20-40 e de 40-100 cm de profundidade.
A comparação entre as curvas de concentrações de $\mathrm{S}$ e de $\mathrm{N}$ indicou que a movimentação do $\mathrm{N}^{-} \mathrm{NO}_{3}{ }^{-}$foi maior do que a de $\mathrm{SO}_{4}{ }^{2-}$. Na camada superficial, as curvas de $\mathrm{N}_{-} \mathrm{NO}_{3}{ }^{-}$evidenciaram alguma semelhança com as curvas dos cátions estudados. Acréscimos de $\mathrm{N}$ na solução de solo foram observados com o início do período chuvoso. Esses incrementos de $\mathrm{N}$ devem-se, possivelmente, à decomposição da matéria orgânica.

Dos ecossistemas estudados, verificou-se que o solo sob pastagem é o que mantém menor concentração de $\mathrm{N}-\mathrm{NO}_{3}$ em solução (Figura 5). Nesse solo, também foram obtidos a menor condutividade elétrica e, conseqüentemente, a menor concentração de eletrólitos, indicando avançado grau de degradação e lixiviação.

No solo em estudo sob pastagem, há predominância de capim-gordura. É uma área com mais de 10 anos de pastoreio, ligeiramente erodida e com baixa capacidade de suporte. A compactação do solo devida ao superpastoreio também está presente nessa área, o que facilita o escoamento superficial. Apesar do significativo aporte de excrementos, visto que uma vaca adulta excreta cerca de $9 \mathrm{t} \mathrm{ano}^{-1}$, o que equivale a $60 \mathrm{~kg}$ de $\mathrm{N}, 18 \mathrm{~kg}$ de $\mathrm{P}_{2} \mathrm{O}_{5}$ e $60 \mathrm{~kg}$ de $\mathrm{K}_{2} \mathrm{O}$ (VicenteChandler et al., 1983), verificou-se empobrecimento desse solo em relação aos demais. A baixa concentração de $\mathrm{N}$ nesse solo pode ser atribuída à competição por $\mathrm{N}$ entre a elevada atividade microbiana da rizosfera das forrageiras e o rápido crescimento das raízes. O processo de nitrificação nessas áreas pode levar à perda de cátions por lixiviação.

\section{Ferro na solução de solo}

A concentração de ferro na solução de solo mostrouse bastante variável ao longo do ano (Figura 5), diminuindo em profundidade para todas as coberturas vegetais. O Latossolo sob cafeeiro, assim como o sem cobertura vegetal, apresentou média mensal de 9,0; 4,1; e 4,1 $\mu \mathrm{mol} \mathrm{L}^{-1}$ de Fe em solução, nas camadas de $0-20,20-40$ e $40-100 \mathrm{~cm}$ de profundidade, respectivamente. Com relação aos Argissolos sob mata e pastagem, as concentrações médias mensais de ferro foram de 72,$5 ; 26,7 ; \mathrm{e} 13,3 \mu \mathrm{mol} \mathrm{L} \mathrm{L}^{-1}$, nas camadas de $0-20,20-40$ e $40-100 \mathrm{~cm}$ de profundidade, respectivamente.

Em solos bem drenados, a concentração de ferro em solução é baixa. Elkhatib et al. (1987) e Mongia (1997) encontraram valores de Fe em solução variando de 0,18 a $1,43 \mu \mathrm{mol} \mathrm{L}^{-1}$, na camada superficial de solo. Em solos argilosos, Campbell et al. (1989) encontraram valores de $\mathrm{Fe}^{2+}$ em solução variando de 2,1 a $2,6 \mu \mathrm{mol} \mathrm{L}{ }^{-1}$, enquanto, em solos arenosos, a variação foi de 7,0 a $14,0 \mu \mathrm{mol} \mathrm{L}{ }^{-1}$.

A concentração média mensal de ferro na solução de solo sob pastagem, na camada de $0-20 \mathrm{~cm}$ de profundidade, foi de $129,15 \mu \mathrm{mol} \mathrm{L} \mathrm{L}^{-1}$, bem superior à dos demais solos sob diferentes coberturas vegetais. Em determinados meses, a concentração de ferro em 


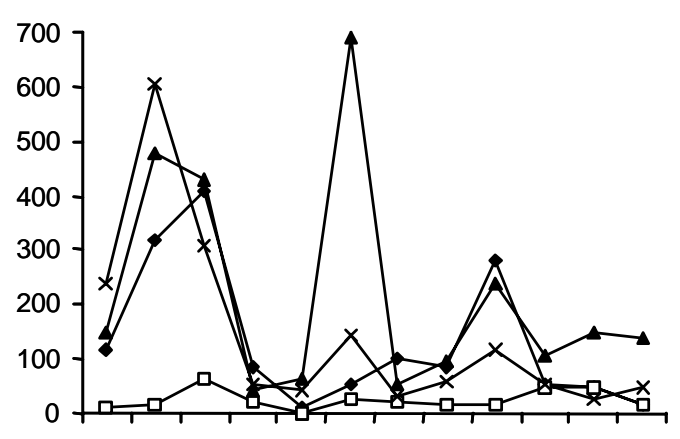

$0-20 \mathrm{~cm}$
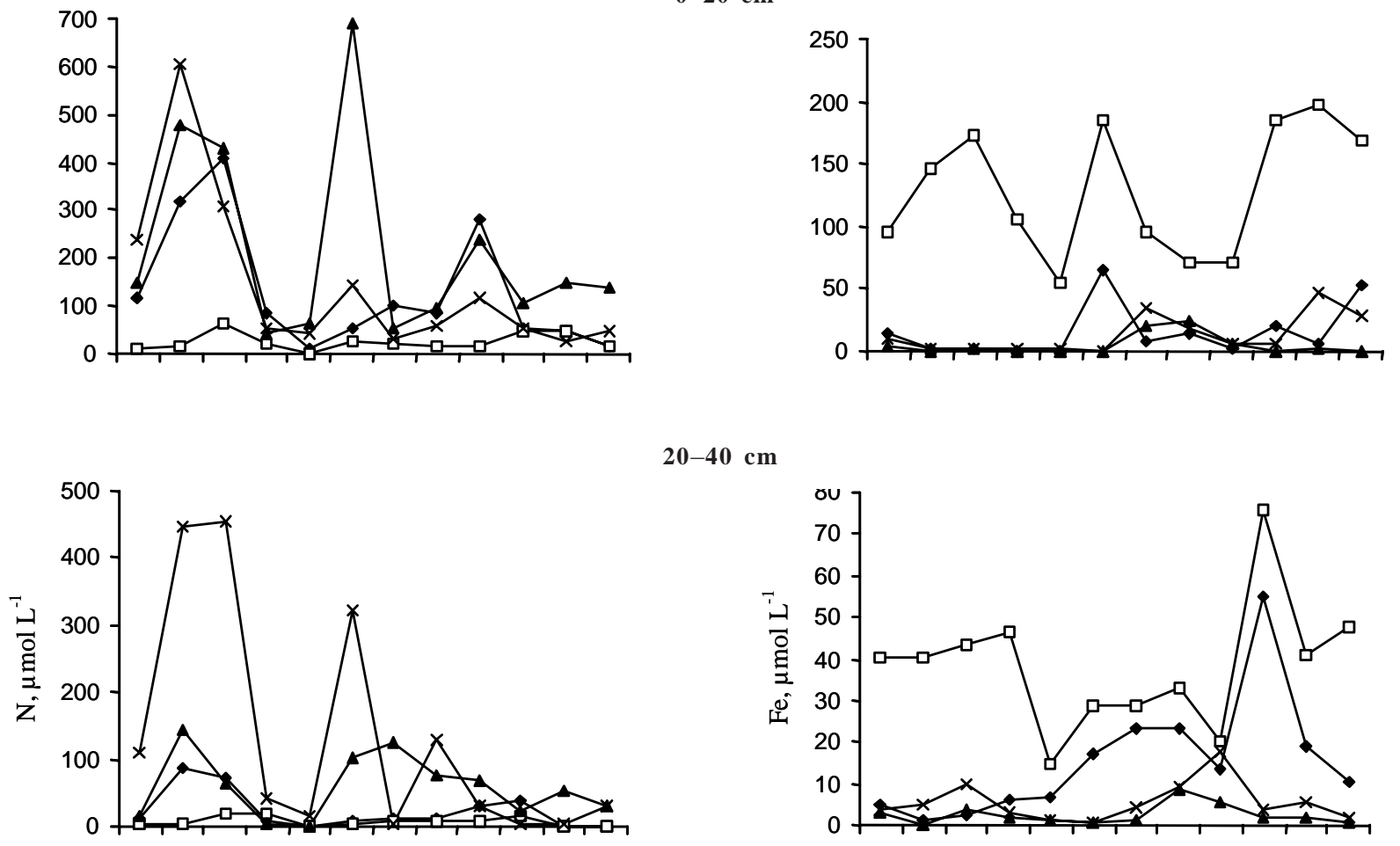

$20-40 \mathrm{~cm}$

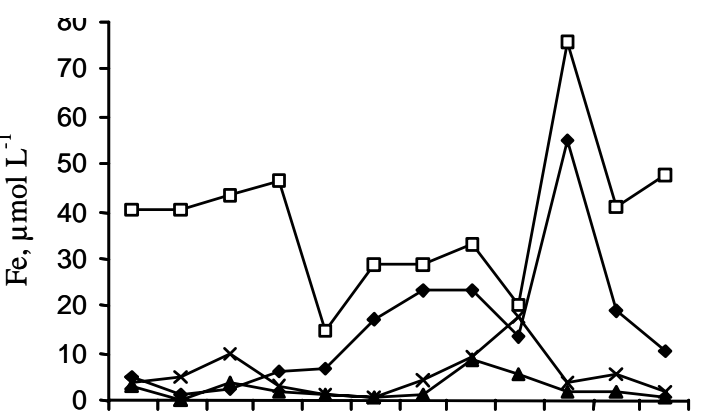

$40-100 \mathrm{~cm}$
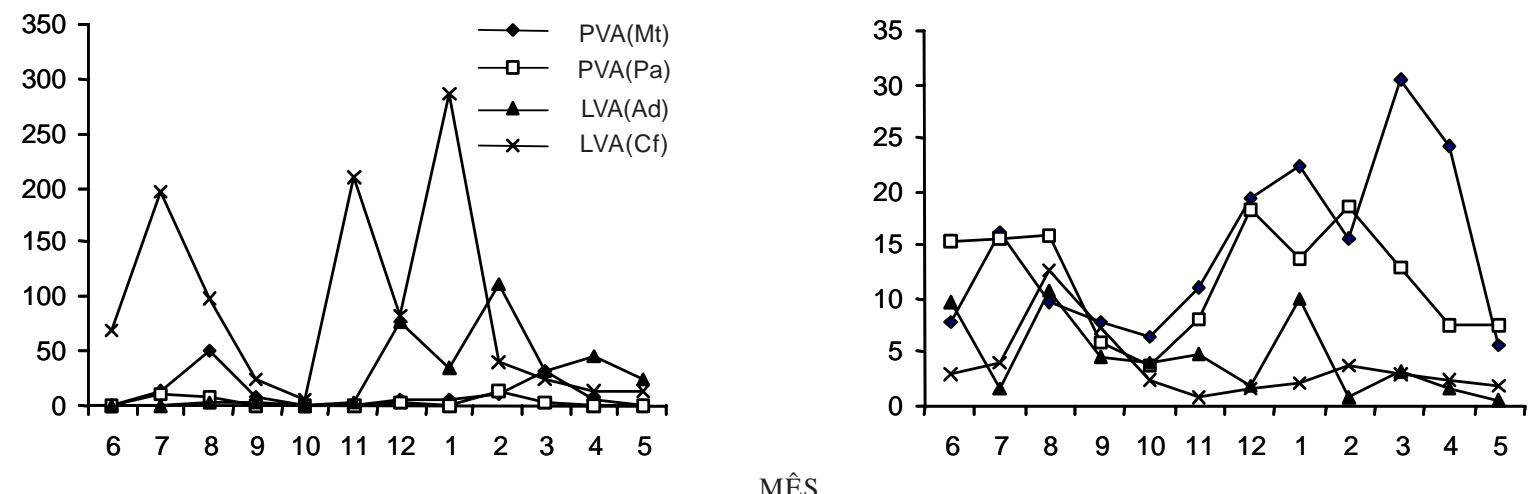

Figura 5. Variação mensal da concentração de nitrogênio nítrico e de ferro na solução do Argissolo Câmbico sob mata (PVA(Mt)) e sob pastagem (PVA(Pa)) e do Latossolo Vermelho-Amarelo sem cobertura vegetal (LVA(Ad)) e sob cafeeiro (LVA(Cf)), no período de junho de 1996 a maio de 1997, em três profundidades. Média de três repetições.

solução chegou a atingir $200 \mu \mathrm{mol} \mathrm{L}-1$ (Figura 5). As amostras de solução especificamente para esse solo apresentavam coloração amarelo-avermelhada. Esse material em suspensão após filtragem ficou retido em membrana com poro de $0,45 \mu \mathrm{m}$. Posteriormente, foi feita a sua caracterização mineralógica por difratometria de raios X, verificando-se a predominância de caulinita e goethita. Aparentemente, esse material em suspensão na solução de solo foi uma associação de material húmico com óxido de ferro (goethita) e caulinita. Essa fração pode translocar-se da superfície para maiores profundidades no perfil, como foi constatado por Fontes et al. (1992). O cultivo intensivo desses solos pode acentuar essa movimentação, cujas estruturas podem percolar no perfil do solo, atingindo os cursos da água, como foi detectado no presente estudo.

\section{Carbono orgânico solúvel na solução de solo}

A concentração média mensal de carbono orgânico solúvel (COS) variou de acordo com a cobertura vegetal. $\mathrm{Na}$ camada de $0-20 \mathrm{~cm}$ de profundidade, a concentração de COS no solo sob mata natural (PVA(Mt)) apresentou os maiores valores. Miranda 
et al. (1996) encontraram maior teor de COS na solução do solo sob mata natural em relação aos solos sob pastagem e eucalipto, assim como correlação positiva e significativa entre carbono orgânico solúvel e carbono orgânico total (COT) do solo. No entanto, isso nem sempre acontece. Andreola (1996), estudando COS em duas épocas de plantio de feijoeiro e três profundidades, só encontrou correlação positiva e significativa entre COS e carbono orgânico do solo em uma época e em uma profundidade.

As concentrações médias de carbono orgânico solúvel no mês nove (setembro de 1996), independentemente da cobertura vegetal, foram de 1,6;0,7; e $0,7 \mathrm{mmol} \mathrm{L}^{-1}$, nas camadas de 0-20, 20-40 e 40-100 cm de profundidade, respectivamente (Figura 6). A partir do nono mês, houve elevação acentuada no teor de COS em todas as camadas e coberturas de solo estudadas, indicando haver associação estreita entre COS em solução e elevação da atividade microbiana decorrente da precipitação pluviométrica e do aumento de temperatura.

O teor de matéria orgânica no solo diminuiu em profundidade em todos os solos. Com relação ao carbono orgânico solúvel, houve ligeira redução em profundidade nos solos sob mata natural, pastagem e sem cobertura vegetal. No entanto, no solo sob cafeeiro (adubado com NPK (20-5-20)), houve ligeira elevação
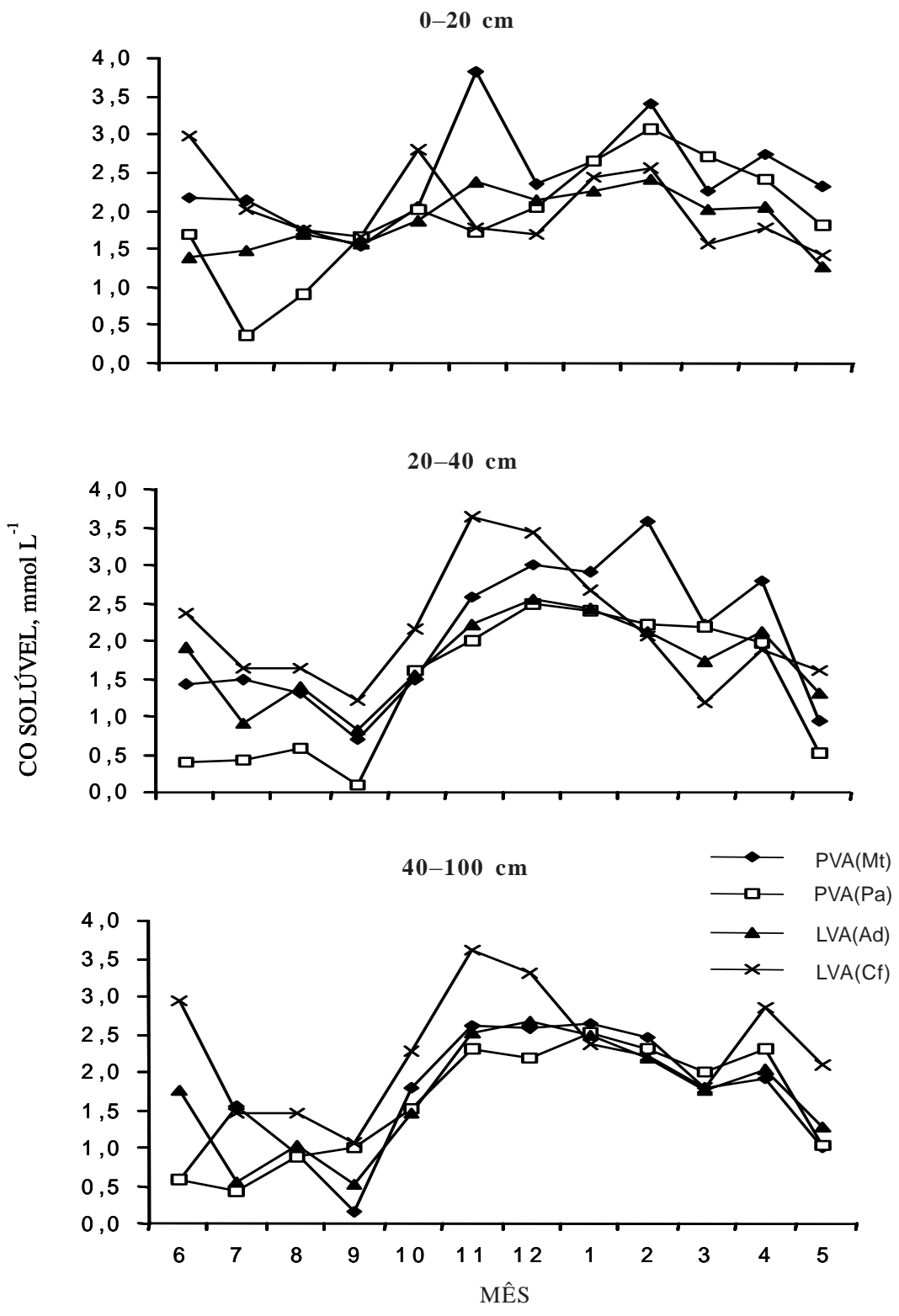

Figura 6. Variação mensal da concentração de carbono orgânico solúvel na solução do Argissolo Câmbico sob mata (PVA(Mt)) e sob pastagem (PVA(Pa)) e do Latossolo Vermelho-Amarelo sem cobertura vegetal (LVA(Ad)) e sob cafeeiro (LVA(Cf)), no período de junho de 1996 a maio de 1997, em três profundidades. Média de três repetições. 
de COS em profundidade (Figura 6). Tal fato indicou que poderia estar ocorrendo translocação de COS em profundidade. Resultados semelhantes foram obtidos por Andreola (1996) em solos cultivados.

Os maiores valores de COS, considerando a profundidade, foram encontrados na solução de solo sob cafezal. Na camada de 40-100 cm, os teores de COS variaram de 1,1 a $3,6 \mathrm{mmol} \mathrm{L}^{-1}$, com média mensal de 2,3 $\mathrm{mmol} \mathrm{L}^{-1}$. Esse solo, dentre os estudados, foi o que apresentou os maiores valores de condutividade elétrica e força iônica e os menores valores de $\mathrm{pH}$. No entanto, de acordo com Evans Jr. et al. (1988), a quantidade de carbono orgânico solúvel e liberado para a solução de solo diminuiu com o aumento da força iônica e aumentou com a adição de $\mathrm{SO}_{4}{ }^{2-}$, indicando que a composição iônica e a força iônica influenciaram o nível de COS em solução.

A solução de solo sob pastagem apresentou uma coloração amarelo-avermelhada, indicando a presença de material em suspensão. Após filtragem da solução e retenção do material em membrana de $0,45 \mu \mathrm{m}$, foi feita a avaliação qualitativa por difratometria de raios $\mathrm{X}$.

Na figura 7, observa-se que a caulinita e goethita predominavam no material em suspensão encontrado na solução de solo sob pastagem. As amostras de solução de solo com coloração amarelo-avermelhada foram também as que apresentaram maior teor de ferro. Tudo indica que esse material é uma associação de substâncias húmicas com óxido de ferro (goethita) e caulinita. Esse material pode translocar-se da superfície do solo, para maiores profundidades no perfil, como foi constatado por Fontes et al. (1992). O cultivo intensivo desses solos pode acentuar a movimentação destes compostos que, ao atingirem o fluxo subterrâneo, podem ser transportados até os cursos da água, acarretando perdas, cujas magnitudes são desconhecidas, tanto de carbono orgânico como de outros elementos complexados.

\section{Carbono orgânico solúvel no deflúvio}

Os valores médios semanais da concentração de carbono orgânico solúvel variaram de 7,3 a 16,6 $\mathrm{mg} \mathrm{L}^{-1}$, respectivamente, no córrego misto e no pasto (Quadro 2).

Azevedo et al. (1996) encontraram concentrações médias de COS no deflúvio de microbacias variando de $0,43 \mathrm{mmol} \mathrm{L}^{-1}$ a 2,39 $\mathrm{mmol} \mathrm{L}^{-1}$. Os maiores teores de COS foram encontrados em microbacias onde predominava o Podzol Hidromórfico, apresentando teores de areia em torno de $85 \%$ no horizonte A.

Verificou-se uma diminuição da concentração de COS nas primeiras seis semanas do período em estudo (Figura 8), quando a ocorrência de precipitação pluvial foi pequena. A partir daí ocorreu elevação da concentração de COS em todos os cursos da água, evidenciando-se que a concentração de carbono orgânico solúvel no deflúvio foi dependente da umidade do solo.

O COS apresentou correlações positivas e significativas com a condutividade elétrica de todos os cursos da água. No curso denominado pasto, onde foram encontradas as maiores concentrações de COS, houve correlação positiva significativa com todos os cátions, exceto com $\mathrm{Mg}^{2+}$. Tal fato indica que o carbono orgânico solúvel pode estar influenciando a movimentação desses elementos no solo. De acordo com Evans Jr. et al. (1988), os ácidos orgânicos são capazes de solubilizar cátions a partir dos componentes inorgânicos do solo via intemperismo mineral. Assim, o aumento das concentrações de COS na solução de solo elevaria a quantidade de espécies orgânicas capazes de solubilizar minerais, aumentando a liberação de cátions em conseqüência do maior intemperismo.

Nos solos sob mata natural e pastagem, foram encontrados teores médios mensais de COS na camada de 0-20 cm de profundidade de, aproximadamente, 2,4 e 1,9 $\mathrm{mmol} \mathrm{L}^{-1}$, respectivamente. Em cursos de água que drenam essas áreas, foram encontrados teores

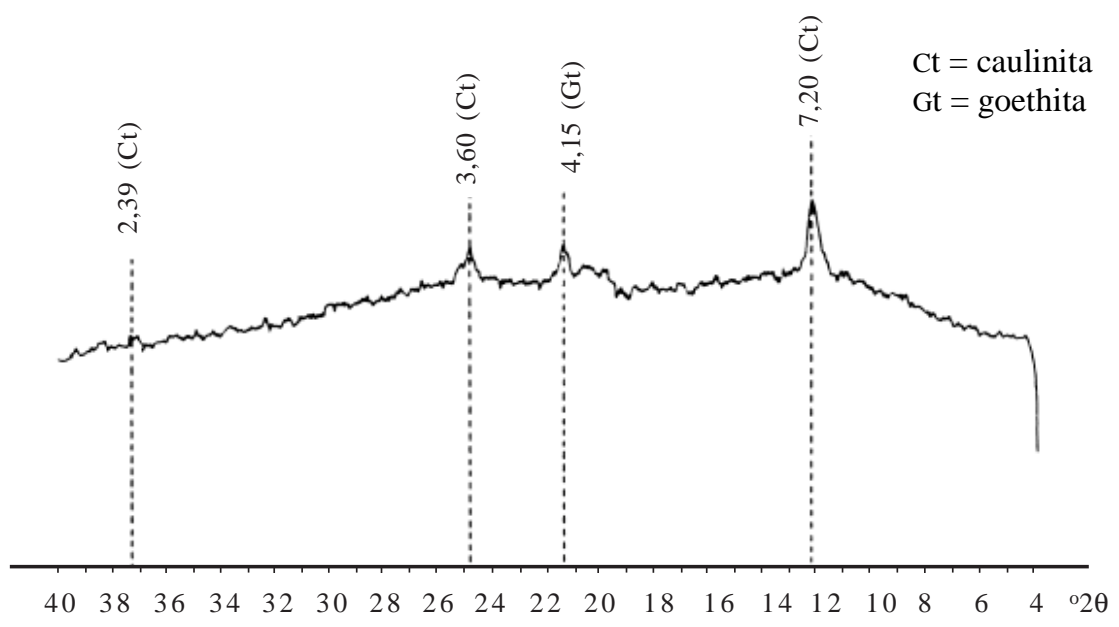

Figura 7. Difratograma de raios X do material em suspensão na solução de solo sob pastagem. 
Quadro 2. pH, condutividade elétrica (CE), carbono orgânico solúvel (COS) e coeficientes de variação médios semanais no deflúvio de cursos da água no período de agosto de 1996 a julho de 1997

\begin{tabular}{|c|c|c|c|c|c|c|}
\hline \multirow{2}{*}{ Curso da água } & \multicolumn{3}{|c|}{ Média } & \multicolumn{3}{|c|}{ Coeficiente de variação } \\
\hline & pH & $\mathrm{CE}$ & $\cos$ & pH & $\mathbf{C E}$ & $\cos$ \\
\hline & & $\mu \mathrm{S} \mathrm{cm}^{-1}$ & $\mathrm{mg} \mathrm{L} \mathrm{L}^{-1}$ & 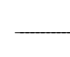 & - $\%$ & - \\
\hline Misto & 6,4 & 78,5 & 7,3 & 4,6 & 24,5 & 60,2 \\
\hline Pasto & 6,2 & 78,6 & 16,6 & 6,1 & 32,5 & 60,3 \\
\hline Mata & 6,5 & 91,5 & 9,9 & 5,3 & 24,1 & 63,1 \\
\hline Represa & 6,6 & 73,7 & 7,9 & 9,7 & 23,0 & 58,9 \\
\hline Média geral & 6,4 & 80,6 & 10,4 & 6,4 & 26,0 & 60,6 \\
\hline
\end{tabular}
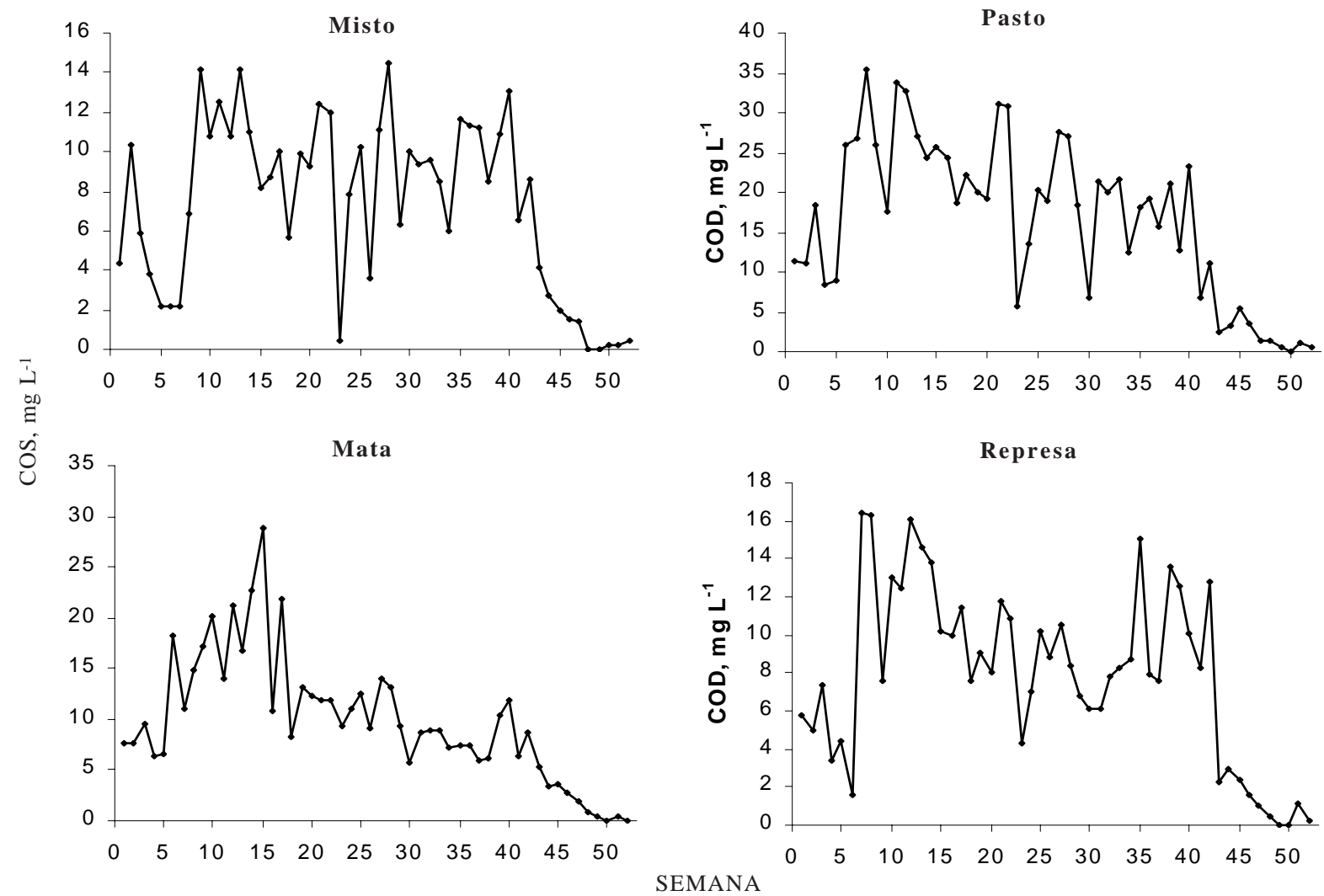

Figura 8. Concentração média semanal de carbono orgânico solúvel no deflúvio de cursos da água no período de 01/08/1996 a 31/07/1997. Média de três repetições.

médios semanais no deflúvio de 0,61 e 1,38 $\mathrm{mmol} \mathrm{L}^{-1}$, em mata e pastagem, respectivamente. Verificou-se, portanto, que a concentração de COS no deflúvio do curso sob pastagem era cerca de $253 \%$ superior ao de mata, apesar de a solução de solo sob mata apresentar maior teor de COS.

$\mathrm{O}$ solo sob mata natural é ligeiramente mais arenoso do que o solo sob pastagem (Quadro 1). Portanto, esperava-se que a movimentação de carbono orgânico solúvel nesse solo fosse maior, aumentando o seu teor no córrego que drena a respectiva área. No entanto, além da textura, a estrutura, mineralogia, mobilidade dos íons, composição química da solução, cobertura vegetal e permeabilidade do solo devem ser consideradas.

De acordo com Meyer (1986), em solos mais arenosos, a perda de COS é maior. Conseqüentemente, córregos que drenam áreas com predominância de solos arenosos têm maior concentração de COS. É o caso dos cursos comumente denominados "água preta", 
resultantes, em parte, da baixa habilidade dos solos arenosos em imobilizar o carbono orgânico solúvel que percola no solo.

Diversos estudos de campo e laboratório evidenciaram que a concentração de carbono orgânico solúvel na solução de solos bem drenados é controlada por óxidos de ferro e alumínio e conteúdo de carbono orgânico do solo. Em terras úmidas que compõem a interface entre ecossistemas aquáticos e terrestres, 0 COS tem sido pouco estudado. Nesses solos minerais "intermediários", a interação de COS com $\mathrm{O}_{2}, \mathrm{Fe}$ e Mn promove condições nas quais ocorrem reações de oxidação e redução de Fe e Mn. Quando a oxidação de Fe prevalece, a retenção do carbono orgânico solúvel é elevada, uma vez que óxidos e hidróxidos de Fe ligamse ao COS, precipitando-o e diminuindo a sua concentração na solução (Moore et al., 1992). Entretanto, em condições anaeróbias durante períodos de elevação do lençol freático, condições de redução são criadas, e o $\mathrm{Fe}^{2+}$ (mais solúvel) prevalece (Heyes \& Moore, 1992). O grau de redução do solo diminui a habilidade do solo em precipitar carbono da solução, influindo, assim, na concentração de COS.

Dessa forma, no presente estudo, no solo sob pastagem, o escoamento superficial é acentuado em períodos de maior precipitação pluviométrica, já que o grau de degradação do solo é elevado, havendo, provavelmente, carreamento superficial de COS para o curso da água. Próximo ao curso da água denominado pasto, existe também a formação temporária de pequenas áreas inundadas, quando ocorre elevação do lençol freático. Nessa situação, prevalecem condições de redução, favorecendo a percolação de COS oriundo da solução de solo.

Qualls \& Haines (1992), estudando a biodegradabilidade da matéria orgânica em soluções de solo sob floresta e deflúvio de cursos da água, concluíram que a adsorção, mais que a biodegradação, é, provavelmente, a principal responsável pela baixa concentração de COS no substrato de solos minerais, prevenindo a sua percolação para os córregos.

\section{CONCLUSÕES}

1. Em geral, houve ligeira elevação na concentração de íons em solução com o início do período chuvoso, sendo esse fato mais acentuado para o carbono orgânico solúvel na solução de solos e no deflúvio.

2. O pH da solução foi superior ao do solo, independentemente da cobertura vegetal e da profundidade, em razão, provavelmente, da retirada de $\mathrm{CO}_{2}$ da solução.

3. A adubação mineral com a fórmula $20-5-20$ aplicada no LVA(Cf) e LVA(Ad) promoveu o deslocamento de cátions trocáveis do solo para a solução em profundidade. A lixiviação foi favorecida, principalmente, no solo sem cobertura vegetal.

4. Em solo sob pastagem, a movimentação de carbono orgânico solúvel foi maior em comparação com a do solo sob mata natural. O solo sob pastagem apresentou, também, valores mais elevados de ferro em solução, que, associado ao COS, movimentou-se ao longo do perfil.

5. As maiores concentrações médias de carbono orgânico solúvel encontradas no deflúvio, cuja área de drenagem é coberta com pastagem, indicaram maior movimentação de carbono na solução desse solo.

6. A solução de solo mostrou-se sensível para detectar os efeitos advindos do uso e manejo do solo, constituindo uma técnica adequada para monitorar as atividades antrópicas nos diversos ecossistemas.

\section{LITERATURA CITADA}

ADAMS, F.; BURMESTER, C.; HUE, N.U. \& LONG, F.L. A comparison of column-displacement and centrifuge methods for obtaining soil solutions. Soil Sci. Soc. Am. J., 44:733-735, 1980 .

ALEXANDER, M. Introduction to soil microbiology. New York, John Wiley, 1977. 472p.

ANDREOLA, F. Propriedades físicas e químicas do solo e produção de feijão e de milho em uma terra roxa estruturada em resposta à cobertura vegetal de inverno e à adubação orgânica e mineral. Viçosa, MG, Universidade Federal de Viçosa, 1996. 103p. (Tese de Doutorado)

AZEVEDO, E.C.; FONTES, L.E.F.; COSTA, L.M. \& SILVA, J.G.M. Carbono orgânico solúvel no deflúvio de microbacias hidrográficas cobertas com mata nativa, pastagem e Eucalyptus grandis. R. Ceres, 43:755-767, 1996.

BARTLETT, R.J. \& ROSS, S.D. Colorimetric determination of oxidizable carbon in acid soil solutions. Soil Sci. Soc. Am. J., 52:1191-1192, 1988.

CAMPBELL, D.J.; KINNIBURGH, D.G. \& BECKETT, P.H.T. The soil solution chemistry of some oxfordshire soils: temporal and spatial variability. J. Soil Sci., 40:321-339, 1989.

CATALDO, D.A.; SCHRADER, L.E. \& YOUNGS, V.L. Analysis by digestion and colorimetric assay of total nitrogen in plant tissues high in nitrate. Crop. Sci., 14:854-856, 1974.

CHAVES, C.D.; PAVAN, M.A. \& MIYAZAWA, M. Especiação química da solução do solo para interpretação da absorção de cálcio e alumínio por raízes de cafeeiro. Pesq. Agropec. Bras., 26:447-453, 1991.

CHESNIN, L. \& YIEN, C.H. Turbidimetric determination of available sulfates. Proc. Soil Sci. Soc. Am., 15:149-151, 1950. 
CURTIN, D. \& SMILLIE, G.W. Effects of incubation and $\mathrm{pH}$ on soil solution and exchangeable cations ratios. Soil Sci. Soc. Am. J., 59:1006-1011, 1995.

DAVID, M.B. \& LAWRENCE, G.B. Soil and soil solution chemistry under red spruce stands across the northeastern United States. Soil Sci., 161:314-328, 1996.

ELKHATIB, E.A.; HERN, J.L. \& STANLEY, T.E. A rapid centrifugation method for obtaining soil solution. Soil Sci. Soc. Am. J., 51:578-583, 1987.

EVANS Jr.; A.; ZELAZNY, L.W. \& ZIPPER, C.E. Solution parameters influencing dissolved organic carbon levels in three forest soils. Soil Sci. Soc. Am. J., 52:1789-1792, 1988 .

FONTES, M.R.; WEED, S.B. \& BOWEN, L.H. Association of microcrystalline goethite and humic acid in some oxisols from Brazil. Soil Sci. Soc. Am. J., 56:982-990, 1992.

GILLMAN, G.P. A centrifuge method for obtaining soil solution. Melbourne, CSIRO, 1976. 6p. (Dv. Soils Rep., 16)

HEYES, A. \& MOORE, T.R. The influence of dissolved organic carbon and anaerobic conditions on mineral weathering. Soil Sci., 154:226-236, 1992.

MARSH, K.B.; TILLMAN, R.W. \& SYERS, J.K. Charge relationships of sulfate sorption by soils. Soil Sci. Soc. Am. J., 51:318-323, 1987.

MCLEAN, E. O. Aluminum. In: AMERICA SOCIETY OF AGRONOMY. Methods of soils analysis II. Madison, 1965. p.778-998. (Agronomy, 9)

MENDONÇA, E.S.; MOURA FILHO, W. \& COSTA, L.M. Organic matter and chemical characteristics of aggregates from a Red-Yellow Latosol under natural forest, rubber plant, and grass in Brazil. In: WILSON, W.S. (Ed.). Advances in soil organic matter research: the impact on agriculture and the environment. Cambridge: The Royal Society of Chemistry, 1991 p.185-195.

MENZIES, N.W.; BELL, L.C. \& EDWARDS, D.E. Exchange and solution phase chemistry of acid, highly weathered soils. I. characteristics of soils and the effects of lime and gypsum amendments. Aust. J. Soil. Res., 32:251-267, 1994.

MEYER, J.L. Dissolved organic carbon dynamics in two subtropical blackwater rivers. Arch. Hydrobiol., 108:119. 134, 1986.
MIRANDA, J. Caracterização da solução do solo e das propriedades físicas e químicas de um Latossolo VermelhoAmarelo sob diferentes coberturas vegetais. Viçosa, MG, Universidade Federal de Viçosa, 1993. 65p. (Tese de Mestrado)

MIRANDA, J.; COSTA, L.M.; RUIZ, H.A. \& MENDONÇA, E.M. Caracterização química de soluções extraídas de um latossolo vermelho-amarelo sob diferentes cobertura vegetais. R. Ceres, 43:139-146, 1996.

MONGIA, A.D. Effect of liming on composition of soil solution in acid soils J. Ind. Soc. Soil Sci., 45:187-189, 1997.

MOORE, T.R.; SOUZA, W. \& KOPRIVNJAK, J.F. Controls of the sorption of dissolved organic carbon by soils. Soil Sci., 154:120-129, 1992.

PAVAN, M.A. Alumínio em solos ácidos do Paraná: relação entre o alumínio não-trocável, trocável e solúvel, com o $\mathrm{pH}, \mathrm{CTC}$, porcentagem de saturação de $\mathrm{Al}$ e matéria orgânica. R. Bras. Ci. Solo, 7:39-46, 1983.

QUALLS, R.G. \& HAINES, B.L. Biodegradability of dissolved organic matter in forest through fall, soil solution and stream water. Soil Sci. Soc. Am. J., 56:578-86, 1992.

QUIAN, P.; WOLT, J.D. \& TYLER, D.D. Soil solution composition as influenced by tillage and time of nitrogen fertilization. Soil Sci., 158:141-149, 1994.

RAIJ, B. van. Fertilidade do solo e adubação. Piracicaba, CERES, POTAFOS, 1991. 434p.

ROSS, D.S. \& BARTLETT, J.R. Field-extracted spodosol solutions and soils: aluminum, organic carbon, and $\mathrm{pH}$ interrelationships. Soil Sci. Soc. Am. J., 60:589-595, 1996.

SIMARD, R.R.; EVANS, L.J. \& BATES, T.E. The effects of additions of $\mathrm{CaCO} 3$ and $\mathrm{P}$ on the soil solution chemistry of a podzolic soil. Can. J. Soil Sci., 68:41-52, 1988.

SU, C. \& EVANS, L.J. Soil solution chemistry and alfafa response to $\mathrm{CaCO}_{3}$ and $\mathrm{MgCO}_{3}$ on an acid Gleysol. Can. J. Soil Sci., 76:41-47, 1996 .

VICENTE-CHANDLER, J.; CARO-COSTAS, R.; ABRUNA, F. \& SILVA, S. Producción y utilización intensiva de las forraseras en Puerto Rico. Rio Piedras, Universidad de Puerto Rico, 1983. 38p.

WOLT, J. \& GRAVEL, J.G. A rapid routine method for obtaining soil solution using vacuum displacement. Soil Sci. Soc. Am. J., 50:602-605, 1986. 